\title{
Non-Contrast Computed Tomography and the Impact of Stone Density to Choose Minimal Invasive Treatment
}

\begin{abstract}
IOAN SCARNECIU1,2, ALEXANDRU BANUTA2, LAURIAN MAXIM1,2*, SALVATORE GIORDANO ${ }^{2}$, DRAGOS RADU MARCU 3,4 , ROXANA BOHILTEA ${ }^{3,5}$, FLORENTINA IONITA-RADU ${ }^{6}$, FLAVIA LILIANA TURCU ${ }^{3,7}$, BOGDAN SOCEA ${ }^{3,8}$, GHEORGHITA ISVORANU ${ }^{9}$, CAMELIA CORNELIA SCARNECIU1,2

'University of Transilvania Faculty of Medicine, 56 th Nicolae Balcescu Str., 500019, Brasov, Romania

${ }^{2}$ Clinical Emergency County Hospital, 25-27th Bucharest Road, 500326, Brasov, Romania

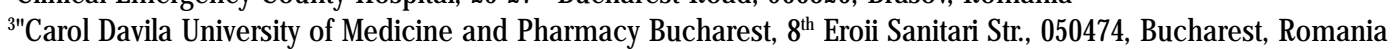

${ }^{4}$ Department of Urology, Dr. Carol Davila Emergency University Central Military Hospital, $88^{\text {th }}$ Mircea Vulcanescu Str., 010825, Bucharest, Romania

${ }^{5}$ Department of Obstetrics and Gynecology, Emergency University Hospital, 169 ${ }^{\text {th }}$ Splaiul Independenei Str., 050098, Bucharest, Romania

${ }^{6}$ Department of Gastroenterology, Dr. Carol Davila Emergency University Central Military Hospital, 88 $8^{\text {th }}$ Mircea Vulcanescu Str., 010825, Bucharest, Romania

${ }^{7}$ Department of Nephrology and Dialysis, St. John Emergency Clinical Hospital, 13 ${ }^{\text {th }}$ Vitan-Barzesti Road, 042122, Bucharest, Romania

${ }^{8}$ Sfantul Pantelimon Clinical Emergency Hospital, 340-342 ${ }^{\text {nd }}$ Pantelimon Road, 021659, Bucharest, Romania

'Victor Babes National Institute of Pathology, 99-1015 Splaiul Independenei, 050096, Bucharest, Romania

Reno-ureteral lithiasis is a common pathology especially in socio-economically developed countries and may pose serious problems with renal function impairment. Urology is currently one of the surgical branches that benefit from a wide range of therapeutic options in reno-ureteral lithiasis, that revolutionized the criteria and indications of the lithiasis pathology, increasing the success rate and decreasing the number of days of hospitalization but which cannot provide satisfactory results if not complemented by imaging examinations. Non-contrast computer tomography is a key element in determining the best method of treatment by measuring the density of stones and increasing the stone-free rate of patients. Measurement of the stones density is done by Hounsfield units (HU), and patients who have had a $<500 \mathrm{HU}$ density have pleaded in over $90 \%$ for the uric acid composition. We included in our study a batch of 364 patients with reno-ureteral lithiasis and the treatment method was chosen based on the density of the stones: $64.83 \%$ of the patients with a density between 200-700 HU performed semi-rigid ureteroscopy and ballistic lithotripsy, 3.57\% of patients with density between 700-1000 HU benefited from flexible ureteroscopy and laser lithotripsy, $17.58 \%$ of patients with density between $400-700 \mathrm{HU}$ performed ESWL and $13.73 \%$ with density> $1000 \mathrm{HU}$ have benefited from PCNL.
\end{abstract}

Key words: non-contrast computer tomography, stones density, minimal invasive therapy, outcome

The incidence of lithiasis pathology has an impact on the population considering genetic, metabolic, infectious, dietetic, climatic factors and socio-economic status, with $10 \%$ higher rate in developed countries, with a significant increase of $37 \%$ over the last 20 years [1-5].

Computed tomography (CT) with no contrast is considered the gold standard investigation in reno-ureteral lithiasis pathology [6-9], providing information on localization, density and size of the stones [10-13].

The quantification of stones density can be a useful tool in the treatment of reno-ureteral lithiasis as measured in Hounsfield (HU) units. Uric acid tones usually range from 200-400 HU, while calcium oxalate stones are approximately 600-1200 HU [6].

The currently available management methods are extracorporeal shockwave lithotripsy (ESWL), ureterorenoscopy (URS) and percutaneous nephrolithotomy (PCNL) being successfully applied for urological patients with reno-ureteral lithiasis [14]. Because of its non-invasive and practical nature, ESWL is the preferred treatment option, but its success depends on the location of the stones [15] and their density and dimensions and often needs alternatives analgesic methods [16,17].

The negative predictors of ESWL success are represented by changes in infundibulum-pelvic angle, narrow infundibulum, or a length of $>10 \mathrm{~mm}$ of the lower calyces $[18,19]$. Open surgery or laparoscopic surgery are the last alternative approaches if minimally invasive methods are not available or unsuccessful.

URS has greater chances to reach stone-free status through a single session, but at the same time shows higher rates of complications [20].

The objectives of our study were to evaluate the stones density on computed tomography with no contrast using Housenfield units and the choice for optimal treatment.

\section{Experimental part \\ Material and methods}

In our study we included 364 patients (224 men, 140 women) in a two-year period (October 2016-October 2018) with symptomatic reno-ureteral lithiasis and different types of treatment, depending on the stone density after CT examination without contrast.

One lot of patients diagnosed with ureteral lithiasis were treated by semi-rigid ureteroscopy (URS) and ballistic lithotripsy in the Clinical Department of Urology within the Clinical County Hospital of Brasov. All other patients with renal and ureteral lithiasis were guided to other medical centers where other therapeutic methods could be used (flexible urethroscopy, ESWL, PCNL). 


\section{Results and discussions}

Following the CT examination, we assessed the urinary stones density using the Hounsfield units, and divided the group in three lots: group A: 236 patients who had a density of stones $\leq 700 \mathrm{HU}$, group B: 13 patients had a density of 700 and $1000 \mathrm{HU}$ and group C: 50 patients had stones with density > $1000 \mathrm{HU}$.

The maximum dimension of the stones was measured on the largest, the longitudinal or the transverse image. The size of the calculus was between 8 and $35 \mathrm{~mm}$, with an average of $12.2 \pm 3.6 \mathrm{~mm}$. Regarding the localization of the stones, 170 patients had left kidney stones, 180 patients presented the pathology on the right kidney and 14 patients had bilateral lithiasis. Of the total group, 62 presented the stones intro the renal pelvis, 29 patients had caliceal stones and 273 ureteral stones. All patients were examined through hematological, biochemical and urinal tests.

The management of the cases were depended on the stones dimension and density (measured through CT examination). For 235 patients with calculus densities

Table 1

CHARACTERISTICS OF THE PATIENTS WITH KIDNEY STONES

\begin{tabular}{|c|c|c|}
\hline \multicolumn{2}{|l|}{ VARIABLES } & NUMBER (\%) \\
\hline \multicolumn{2}{|l|}{ Number of patients } & 364 \\
\hline \multirow[t]{2}{*}{ Gender } & Male & $224(61.53 \%)$ \\
\hline & Female & $140(38.46 \%)$ \\
\hline \multicolumn{3}{|l|}{ Density of the stones } \\
\hline & $<700 \mathrm{HU}$ & $120(32.97 \%)$ \\
\hline & $700-1000 \mathrm{HU}$ & $194(53.30 \%)$ \\
\hline & $=1000 \mathrm{HU}$ & $50(13.73 \%)$ \\
\hline \multicolumn{2}{|l|}{ Stone dimensions } & $\begin{array}{l}8-35 \quad \mathrm{~mm} \\
\text { (average } 18.2 \pm \\
3.6 \text { ) }\end{array}$ \\
\hline \multirow[t]{3}{*}{ Localization of the stones } & Left & $170(46.70 \%)$ \\
\hline & Right & $180(49.45 \%)$ \\
\hline & Bilateral & $14(3.85 \%)$ \\
\hline \multirow[t]{5}{*}{ Topography of the stones } & Renal pelvis & $62(17.03 \%)$ \\
\hline & Caliceal & $29(7.97 \%)$ \\
\hline & Ureteral & $273(75 \%)$ \\
\hline & lumbar & $170(62.27 \%)$ \\
\hline & pelvic & $66(37.73 \%)$ \\
\hline
\end{tabular}

between 200-700 HU therapeutic management consisted of semi-rigid ureteroscopy with ballistic lithotripsy, 13 patients with calculus densities between 700-1000 HU benefited from flexible ureteroscopy and laser lithotripsy, in 64 patients with the density of stones between 400-700 $\mathrm{HU}$ it was performed extracorporeal shock wave lithotripsy and in 50 patients with calculus density $>1000 \mathrm{HU}$, percutaneous nephrolithotomy was performed (table 1 and 2).

Patients whose stones who presented lithiasis at ureteral level presented also ureterohydronephrosis and increased creatinine levels, arterial hypertension [21-25], complications that necessitated more complex therapeutically and perioperative management [26-29], such as double J internal ureteral drainage for ureterohydronephrosis remission and creatinine levels normalization.

Knowing the radioactivity of urinary stones provides urologists with valuable information for choosing the therapeutic method for each category, including long-term post-procedural imaging monitoring. Computer tomography was a real advantage in the case of radiotransparent stones, preventing unnecessary serial radiographies and exposure to unjustified radiation doses.

A study by Spettel et al pointed out the importance of knowing the density of stones, which can definitely influence the response to the therapy. Thus, patients who presented stones whose density $<500 \mathrm{HU}$, pleaded in over $90 \%$ for the uric acid composition. Also, in the same study it was demonstrated that stones with a density of $<500$ $\mathrm{HU}$ are radiotransparent, which once again highlights the need for CT examination [30].

ESWL therapy was conducted under fluoroscopic guidance with a frequency of 65 pulses / min and a maximum of 4000 shocks / session. Patients were monitored for at least $2 \mathrm{~h}$ post-procedural and then discharged under day-care regimen. For 40 patients one ESWL session was performed, 20 patients benefited from two sessions and 4 patients three ESWL sessions had to be made at a distance of 2 weeks, with maximum duration of therapy being 6 weeks. Patients included in our uric acid structure study were treated with drug chemotherapy to reach stone-free status after ESWL. The analysis of the stones was carried out in all cases when fragments were available.

In the group of patients with stones densities between 700 and $1000 \mathrm{HU}$, the same study demonstrates that they are radiological visible at a density of over $800 \mathrm{HU}$. In these patients, the therapy used was ureteroscopy and laser lithotripsy.

Table 2

TREATMENT OF THE PATIENTS WITH KIDNEY STONES ACCORDING TO THE DENSITY OF THE STONE

\begin{tabular}{|l|l|l|}
\hline Density of the stone & Treatment applied & No. (\%) \\
\hline $200-700 \mathrm{UH}$ & $\begin{array}{l}\text { semi-rigid ureteroscopy and } \\
\text { ballistic lithotripsy }\end{array}$ & $\mathbf{2 3 6}(64.83 \%)$ \\
\hline $700-1000 \mathrm{UH}$ & $\begin{array}{l}\text { Flexible ureteroscopy + laser } \\
\text { lithotripsy }\end{array}$ & $\mathbf{1 3}(3.57 \%)$ \\
\hline $400-700 \mathrm{UH}$ & ESWL & $64(17.58 \%)$ \\
\hline$>1000$ & PCNL & $\mathbf{5 0 ( 1 3 . 7 3 \% )}$ \\
\hline & & \\
\hline & &
\end{tabular}


Using laser lithotripsies, trauma of the urothelium [3135] is usually lower compared to other types of lithotripsies [36] but considering the fragmentation rate of $90-96 \%$ and lower costs compared to laser fibers [37], we used the ballistic lithotomy with the $2.4 \mathrm{~F}$ probe that was inserted through the semi-rigid ureteroscope with a stone free rate of $98 \%$ of cases after fitting a 4.8-6-6 Ch ureteral stent with a $24-25 \mathrm{~cm}$ length of polyurethane aliphatic material. The choice of the type of stent was made on the basis of the results of the prospective study of Scarneciu et al. which demonstrates that choosing the type of stent depending on the composition does not bring benefits in terms of the patient's quality of life during stenting [38].

Patients with stones density between 700-100 HU required minimally invasive laser lithotripsy therapy using: pulsatile (PE) energy between 0.8 - 1.2 J, impulse frequency between $10-15 \mathrm{~Hz}$ and $200 \mathrm{~mm}$ laser fiber. Particularly, we refer to patients for whom ESWL had poor results due to the density of stones. Numerous studies prove the efficacy of Pulse Energy (Pulse Energy) laser lithotripsy, so the loss of lithium mass is directly proportional to PE increase.

For example, in a study conducted by Kuo et al., the percent mass loss for a treated stone using a 200um laser fiber has doubled and tripled when PE increased from 0.5 to 1.0 and respectively 2.0 ] [39]. A similar observation was also observed in a study by Kronenberg and Traxer [40]. Larger fragments are produced when large PE settings are used compared to the use of lower PE settings [41].

For 50 patients with stone densities > $1000 \mathrm{HU}$ (with caliceal or renal pelvis localization), PCNL was used. In a study by Zhu et al, 865 patients were evaluated and the SF rate was $80.1 \%$ [42].

The post-ureteroscopy stent was a matter of debate for the last decade without a final consensus [43]. It is accepted that a doubleJ stent, after a procedure, eliminates the risk of hydronephrosis due to mucosal edema. On the other hand, the ureteral stent itself is associated with a certain degree of morbidity, including stent infiltration, ureteral mucosal erosion, flank pain and irritant discharge symptoms, especially in patients with previous comorbidities and reduced physiological resources [4447]. Recent comparative studies have shown that procedural costs can be reduced by $30 \%$ if the postoperative stent is avoided [48]. Currently, most urologists avoid patient stenosis as long as ureteroscopy is uncomplicated [49].

\section{Conclusions}

Computed tomography without contrast, can predict the stone free rate by measuring stone density. As we can see from the analysis of the therapeutic success of the patients included in our study, those with stone density ranging from 500 to $800 \mathrm{HU}$ could be treated with ESWL and those with a density $>800 \mathrm{HU}$ by URS associated with Holmium Laser lithotripsy. This information may be beneficial for selecting preferred treatment options for patients with urinary stones. ESWL is not indicated for patients with upper urinary tract stones with high HU values.

\section{References}

1.HESSE, A., BRANDLE, E., WILBERT, D., KOHRMANN, K.U., ALKEN, P., Eur. Urol., 44, no. 6, 2003, p. 709

2.NICULAE, A., PERIDE, I., VINEREANU, V., RADULESCU, D., BRATU, O. G., GEAVLETE, B. F., CHECHERITA, I. A., Rom. J. Morphol. Embryol., 58, no. 3, 2017, p. 1065
3.NICULAE, A., PERIDE, I., MARINESCU-PANINOPOL, A., VRABIE, C.D., GINGHINA, O., JECAN, C.R., BRATU, O.G., Rom. J. Morphol. Embryol., 57, no. 2, 2016, p. 591

4.RADULESCU, D., BALCANGIU STROESCU, A., PRICOP, C., GEAVLETE, B., NEGREI, C., BRATU, O., GINGHINA, O., VACAROIU, I., Rev. Chim. (Bucharest), 68, no. 1, 2017, p. 52

5.PRICOP, C., SUDITU, N., VRINCEANU, R., PUIA, D., CATALIN, D.C., CIUTA, L.T., CHECHERITA, I.A., Prevalence, 19, 2015, p. 24

6.NAKADA, S.Y., HOFF, D.G., ATTAI, S., HEISEY, D., BLANKENBAKER, D., POZNIAK, M., Urol., 55, no. 6, 2000, p. 816

7.MARCU, R.D., SPINU, A.D., SOCEA, B., BODEAN, M.O., DIACONU, C.C., VASILESCU, F., NEAGU, T.P., BRATU, O.G., Rev. Chim. (Bucharest),

69, no. 4, 2018, p. 823

8.PAHONTU, E., SOCEA, L.I., BARBUCEANU, S.F., ILIES, D.C., BADEA, M., OLARU, O. T., GULEA, A., SOCEA, B., BRATU, O., Rev. Chim. (Bucharest), 69, no. 11, 2018, p. 2959

9.SPINU, A.D., MARCU, R.D., SOCEA, B., DIACONU, C.C., SCARNECIU, I., SCARNECIU, C., BODEAN, O. M., DRAGOMIRESCU, R. I. F., STANESCU, A. M. A., MISCHIANU, D. L. D., BRATU, O. G., Rev. Chim. (Bucharest), 69, no. 8, 2018, p. 2061

10.BRATU, O.G., MARCU, R.D., SOCEA, B., NEAGU, T.P., DIACONU, C.C., SCARNECIU, I., TURCU, F.L., RADAVOI, G.D., BRATILA, E., BERCEANU, C., SPINU, A.D., Rev. Chim. (Bucharest), 69, no. 7, 2018, p. 1813

11.BRATU, O., MISCHIANU, D., SPINU, D., BARLA, R., HOARA, P., CONSTANTINOIU, S., Chirurgia (Bucur), 108, no. 1, 2013 p. 26

12.CONSTANTINOIU, S., BARLA, R., IOSIF, C., COCIU, L., GINDEA, C., HOARA, P., BRATU, O., RUSITORU, L., Chirurgia (Bucur), 104, no. 3, 2009, p. 363

13.SCARNECIU, I., ANDREI, C., SCARNECIU, C., LUPU, A.M., BRATU, O.G., LUPU, S. Urol J, 15, no. 5, 2018, p. 297

14.PRICOP, C., NEGRU, I., CIUTA, C., JINGA, V., ILIE'IU, A., CHECHERITA, I.A., TODOSI, L., RADAVOI, D., JINGA, M., Farmacia, 64, no. 5, 2016, p. 757

15.TURNA, B., AKBAY, K., EKREN, F., et al., Int. Urol. Nephrol., 40, no. 1,2008, p. 23

16.NEAGU, T.P., COCOLOS, I., COBILINSCHI, C., TIGLIS, M., FLORESCU, I.P., BADILA, E., SINESCU, R.D., Rev. Chim. (Bucharest), 68, no. 12, 2017, p. 2978

17.TIGLIS, M., NEAGU, T.P., ELFARA, M., DIACONU, C.C., BRATU, O.G., VACAROIU, I.A., GRINTESCU, I.M., Rev. Chim. (Bucharest), 69, no. 10, 2018, p. 2877

18.KOSAR, A., OZTURK, A., SEREL, T.A., AKKUS, S., UNAL, O.S., J. Endourol., 13, no. 10, 1999, p. 705

19.ALBANIS, S., ATHER, H.M., PAPATSORIS, A.G., et al., Urol. Int., 83, 2009, p. 211

20.PEREZ CASTRO, E., OSTHER, P.J., J INGA, V., et al., Eur. Urol., 66, no. 1, 2014, p. 102

21.DIACONU, C.C., MANEA, M., IANCU, M.A., STANESCU, A.M.A., SOCEA, B., SPINU, D.A., MARCU, D., BRATU, O.G., Rev. Chim. (Bucharest), 69, no. 5, 2018, p. 1071

22.DIACONU, C.C., DRAGOI, C.M., BRATU, O.G., NEAGU, T.P., PANTEA STOIAN, A., COBELSCHI, P.C., NICOLAE, A.C., IANCU, M.A., HAINAROSIE, R., STANESCU, A.M.A., SOCEA, B., Farmacia, 66, no. 3, 2018, p. 408

23.DIACONU, C.C., STANESCU, A.M.A., PANTEA STOIAN, A., TINCU, R.C., COBILINSCHI, C., DRAGOMIRESCU, R.I.F., SOCEA, B., SPINU, D.A., MARCU, D., SOCEA, L.I., BRATU, O.G., Rev. Chim. (Bucharest), 69, no. 6, 2018, p. 1367

24.TICA, O.A., TICA, O., ANTAL, L., HATOS, A., POPESCU, M.I., PANTEA STOIAN, A., BRATU, O.G., GAMAN, M.A., PITURU, S.M., DIACONU, C.C., Farmacia, 66, no. 6, 2018, p. 972

25.MANEA, M., MARCU, D., PANTEA STOIAN, A., GAMAN, M.A., GAMAN, A.M., SOCEA, B., NEAGU, T.P., STANESCU, A.M.A., BRATU, O.G., DIACONU, C.C., Rev. Chim. (Bucharest), 69, no. 11, 2018, p. 4180 26.TIGLIS, M., GRINETESCU, I.C., NEAGU, T.P., TURCU, F.L., COCOLOS, A.M., GRINETESCU, I.M., Rev. Chim. (Bucharest), 69, no. 2, 2018, p. 391 
27.CHECHERITA, I.A., DAVID, C., CIOCALTEU, A., LASCAR, I., Chirurgia (Bucharest), 104, no. 5, 2009, p. 525

28.BADILA ,E., WEISS, AE, BARTOS D, DUMITRACHE EL, TATARANU LG, CIUBOTARU, G,V., NEAGU TP, ENACHE, V., POPA, V.B., JAPIE C. Rom J Morphol Embryol., 58, no. 3, 2017, p. 983

29.CHECHERITA, I.A., DAVID, C.R., DIACONU, V., CIOCALTEU, A., LASCAR, I., Rom J Morphol Embryol., 52, no. 3 Suppl., 2011, p. 1047 30.SPETTEL, S., SHAH, P., SEKHAR, K., HERR, A., WHITE, M.D., Urol., 82, no. 1, 2013, p. 22

31.STANIMIR, M., CHIUTU, L.C., WESE, S., MILULESCU, A., NEMES, R.N., BRATU, O., Rom. J. Morphol. Embryol., 57, no. 2 Suppl, 2016, p. 849

32.RADAVOI, G.D., PRICOP, C., JINGA, V., MATES, D., RADOI, V.E., JINGA, M., URSU, R.I., BRATU, O.G., MISCHIANU, D.L., IORDACHE, P., Rom. J. Morphol. Embryol., 57, no. 2, 2016, p. 467

33.PAHONTU, E., PARASCHIVESCU, C., ILIES, D.C., POIRIER, D., OPREAN, C., PAUNESCU, V., GULEA, A., ROSU, T., BRATU, O., Molecules, 21, no. 5, 2016, doi: 10.3390/molecules21050674 34.MEHEDINTU, C., ANTONOVICI, M., BRINDUSE, L., BRATILA, E., STANCULESCU, R., BERCEANU, C., BRATU, O., PITURU, S., ONOFRIESCU, M., MATASARIU, D. R., Rev. Chim. (Bucharest), 69, no. 3, 2018, p. 581

35.BODEAN, O., BRATU, O., BOHILTEA, R., MUNTEANU, O., MARCU, D.,SPINU, D. A., VACAROIU, I. A., SOCEA, B., DIACONU, C. C., FOMETESCU GRADINARU, D., CIRSTOIU, M., Rev. Chim. (Bucharest), 69, no. 6, 2018, p. 1411

36.SCARPA, R.M., DE LISA, A., PORRUD, U. E., Eur. Urol., 35, 1999, p. 233

37.TAN, P.K., TAN, S.M., CONSIGLIERE, D., J. Endourol., 12, no. 4, 1998, p. 341
38.SCARNECIU, I., LUPU, S., PRICOP, C., SCARNECIU, C., Pak. J. Med. Sci., 31, no. 3, 2015, p. 522

39.KUO, R.L., ASLAN, P., ZHONG, P., PREMINGER, G.M., J. Endourol., 12, no. 6, 1998, p. 523

40.KRONENBERG, P., TRAXER, O., Brit. J. Urol. Int., 114, no. 2, 2014, p. 261

41.SEA, J., JONAT, L.M., CHEW, B.H., QIU, J., WANG, B., HOOPMAN, J., et al., J. Urol., 187, no. 3, 2012, p. 914

42.ZHU, Z., WANG, S., XI, Q., BAl, J., YU, X., LIU, J., Urol, 78, no. 1, 2011, p. 32

43.KNUDSEN, B., BEIKO, D., DENSTEDT, J., Urol. Clin. North. Am., 31, no. 1, 2004, p. 173

44.MIREA, D., MIREA, L.E., NITIPIR, C., TIGLIS, M., GRINPESCU, I.C., NEAGU, T.P., MOGOANTÃ, C.A., GRINTESCU, I.M., Rom J Morphol Embryol., 58, 2017, p. 3

45.GHEORGHISAN-GALATEANU, A., TERZEA, D.C., CARSOTE, M., POIANA, C., J Ovarian Res., 61, no. 1, 2013, p. 28

46.MARCU, R.D., SPINU, A.D., SOCEA, B., BODEAN, M.O., DIACONU, C.C., VASILESCU, F., NEAGU, T.P., BRATU, O.G., Rev. Chim. (Bucharest), 69, no. 4, 2018, p. 823

47.VASIC, J., PETRANOVA, T., POVOROZNYUK, V., BARBU, C.G., KARADZIC, M., GOJ KOVIC, F., ELEZ, J., WINZENRIETH, R., HANS, D., CULAFICVOJ INOVIC, V., POIANA, C., J. Bone Miner. Metab., 32, no. 5, 2014, p. 556

48.NETTO, N., IKONOMIDIS, J., ZILLO, C., J. Urol., 166, no. 4, 2001, p. 1252

49.DENSTEDT, J., WOLLIN, T., SOFER, M., NOTT, L., WEIR, M., HONEY, J., J. Urol., 165, no. 5, 2001, p. 1419

Manuscript received: 27.09 .2018 